\title{
Community signals of the effect of Didymosphenia geminata (Lyngbye) M. Schmidt on benthic diatom communities in Chilean rivers
}

\author{
Jacqueline Salvo Pereira* and Alejandra Oyanedel Pérez
}

\begin{abstract}
Background: Didymosphenia geminata (Lyngbye) M. Schmidt is a freshwater invasive benthic diatom native to oligotrophic systems of the Northern Hemisphere. Since 2010, freshwater systems of south-austral Chile, have experienced a progressive invasion of this species between $37^{\circ} 18^{\prime} \mathrm{S}$ and $54^{\circ} 30^{\prime} \mathrm{S}$. This invaded area is characterized by biogeographic heterogeneity, anthropic pressure and lack of knowledge. The objective of this study was to analyze the effect of $D$. geminata on the community structure of benthic diatoms and the variability of this effect in Chilean rivers.

Methods: The data were collected between 2010 and 2017 and pre-treated using fourth-root transformation to construct a Bray-Curtis similarity matrix and a Principal Coordinate Analysis to identify groups of sites. The $a$ diversity and $\beta$ diversity were estimated and compared using univariate indexes and the Mann-Whitney test, respectively. We used Permutational multivariate analyses of variance (PERMANOVA) and PERMDISP to estimate the spatial variation of communities, and an Analysis of Percentage Similarity (SIMPER) was performed to identify the species which contributed to the similarity between the groups of sites.

Results: The results suggest significant differences between invaded and noninvaded rivers ( $54 \%$ of the total variation); the univariate indexes showed greater richness $(\mathrm{S})$, greater diversity $\left(\mathrm{H}^{\prime}\right)$, and less species turnover in invaded rivers. The PERMANOVA indicated significant interaction between D. geminata and the basins; there was also a significant effect on the internal dispersion in the basins. The SIMPER analysis showed that the groups composed exclusively of invaded sites had high mean similarity in all basins and small pedunculated benthic diatoms showed a significant response to the presence of D. geminata.

Conclusion: We found high variability in the community structures, that determine a strong segregation between noninvaded and invaded sites by D. geminata, and that the main effect of D. geminata on diatoms benthic was the homogenization of the communities. This is reflected in the increase in density of small stalked diatoms and the reduction of species turnover among rivers in the same basin, leading to the loss of community heterogeneity that overcomes the spatial heterogeneity in the area invaded in Chile.
\end{abstract}

Keywords: Invasion, Fluvial, Diversity, Structure, Homogenization

\footnotetext{
* Correspondence: jacqueline.salvo@ifop.cl

Departamento de Medio Ambiente Instituto de Fomento Pesquero, Puerto

Montt, Chile

C The Author(s). 2019, corrected publication. August 2019. Open Access This article is distributed under the terms of the Creative Commons Attribution 4.0 International License (http://creativecommons.org/licenses/by/4.0/), which permits

unrestricted use, distribution, and reproduction in any medium, provided you give appropriate credit to the original author(s) and the source, provide a link to the Creative Commons license, and indicate if changes were made. The Creative Commons Public Domain Dedication waiver (http://creativecommons.org/publicdomain/zero/1.0/) applies to the data made available in this article, unless otherwise stated.
} 


\section{Background}

Biological invasions are among the five greatest threats to freshwater systems in the world $[1,56,58]$. Invasive species may generate negative effects on the resident communities, interfering in the transfer of material and energy and biogeochemical processes, and even acting as engineering species $[31,32,34,60]$. Among the most severe impacts is the alteration of the physical habitat, which can cause exclusion or facilitation of species and conduce to ecological homogenization of the invaded systems $[48,52]$.

The effects generated by invasive species are ubiquitous and varied. Their prediction depends in large part on understanding their interactions with the resident species and the ecological particulars of the invaded communities [49, 70, 71]. Diatoms are an excellent model for the study of the effects of invasive species in freshwater benthic communities. Their wide functional and taxonomic diversity, rapid growth rates and marked response capability to environmental fluctuations allow detecting ecological signals that explain the changes associated with species invasions [50, 63, 68].

Didymosphenia geminata (Lyngbye) M. Schmidt is a stalked freshwater diatom of the Northern Hemisphere that generates mucilaginous proliferation in oligotrophic waters $[6,35]$. D. geminata has expanded rapidly outside its native distribution range in the last decade ([69], successfully invading rivers and lakes of New Zealand, Argentina and southern Chile. [25, 61, 62]. The invaded systems have transparent and cold water with reduced nutrient concentrations; they have low levels of anthropogenic intervention and great recreational importance $[6,8$, 36]. The dispersion of this diatom is mainly associated with human transport by the use of contaminated recreational equipment, e.g. of recreational and sport fishing [8], while the development of large numbers of stalks has mainly been associated with soluble reactive phosphorous concentrations below $2 \mathrm{ppb}$ [7, 9, 43]. The proliferation consists of the massive development of mucilaginous stalks from D. geminata cells, which cover extensive areas of benthic substrate. As a consequence, more homogenous habitats with low levels of hydraulic stress arise, that promote solute interchange and favor the proliferation and expansion of the mucilaginous masses $[11,12,20,46]$. The changes in the physical habitat may displace or favor certain species of the benthos [22], modifying the trophic structure of the aquatic ecosystem [23, 37], which then alter the patterns of alpha and beta diversity at different spatial scales [29, 51, 53].

D. geminata has invaded mainly mountain rivers with low anthropogenic degradation and low nutrient concentrations in Chile from $37^{\circ} 18^{\prime} \mathrm{S}$ to $54^{\circ} 30^{\prime} \mathrm{S}[54,55]$. The area invaded includes different freshwater ecoregions which have different climate, topography and habitats; this area is highly heterogeneous in biogeographic terms [1]. Proliferation of D. geminata was first detected in Chile in Patagonian rivers in the year 2010. However, there were some earlier records from Lago Sarmiento and Río Cisnes [3, 64, 65]. There are few studies of the effects of these proliferations on freshwater communities in Chile, and they have been limited by lack of baseline knowledge of this type of ecosystem. The main effects of D. geminata detected in Chilean rivers include increase of algal biomass, capture of sediments and alteration of hydrodynamic and biogeochemical processes [61]. It has also been observed that in vitro $D$. geminata affects negatively the movement of gametes of the genus Salmo [57].

To understand the invasion process of $D$. geminata, it is crucial to understand its effects on the benthic communities and the fluvial habitat, in order to elucidate its impacts on the integrity of the freshwater ecosystems. Studies have identified significant changes to patterns ecological and taxonomic patterns of freshwater biota in Chile, at varying spatio-temporal scales $[66,72]$. Among them, the spreading of $D$. geminata in suitable river habitats of central-southern Chile [30, 54, 55], which are likely to drive differences in what is known about algal communities $[4,59,65,66]$. Given the extensive range affected by $D$. geminata, we expect the existence of complex and diverse relations expressed in the structure of benthic diatom communities. The objective of this study was to analyze the effect of $D$. geminata on the community structure of benthic diatoms and the variability of this effect in Chilean rivers. We hypothesized that sites invaded by $D$. geminata will share a common community structure, be less diverse and significantly different than sites not invaded by this diatom.

\section{Methods}

\section{Study area}

We considered 1182 samples obtained in rivers from $35^{\circ} \mathrm{S}$ $71^{\circ} \mathrm{W}$ to $54^{\circ} \mathrm{S} 68^{\circ} \mathrm{W}$, covering a latitudinal extension of about $2000 \mathrm{~km}$ (Fig. 1). The area has great hydrological heterogeneity; we considered the rivers of basins where the presence of D. geminata has been detected, including the Biobío (code 83), Toltén (code 94), Valdivia (code 101), Bueno (code 103), Puelo (code 105), Yelcho (code 107), Palena and coastal rivers in the southern limit of the Décima Región (code 110), coastal and island rivers between Río Palena and Río Aysén (code 111), Aysén (code 113) and Baker (code 115) rivers, coastal rivers between Seno Andrew and Río Hollemberg and rivers to the east (code 122), and in Tierra del Fuego (code 128). The rivers sampled are in mountainous ecosystems with a low level of human intervention, with intensive recreational use and of interest for the conservation of biodiversity, which are in the Patagonian, Valdivian Lakes and South Andean Pacific Slope ecoregions according to the classification proposed by Abell et al. [1]. 


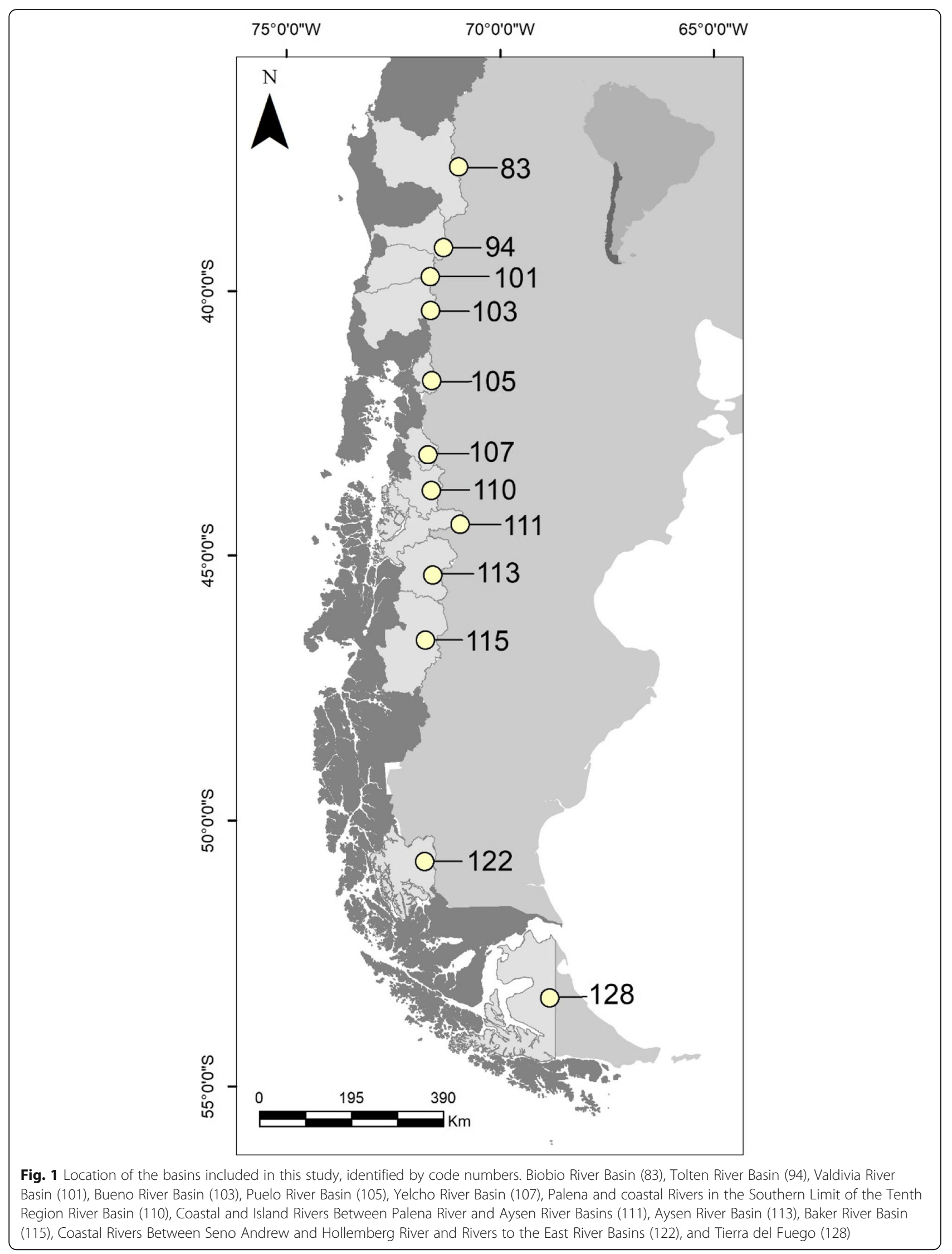




\section{Sampling and species identification}

We analyzed density data $\left(\mathrm{cell} / \mathrm{mm}^{2}\right)$ of benthic diatoms obtained between 2010 and 2017 in the context of different monitoring programs of the Undersecretariat for Fisheries and Aquaculture (SUBPESCA) of the Chilean government, using as reference the standard sampling protocol for the study of periphyton and D. geminata $[17$, 45]. Diatom samples were obtained from $50 \mathrm{~m}$ transects of a river section; 5 rocks with evident presence of periphyton were selected randomly. We marked a $4 \mathrm{~cm}^{2}$ area of each rock, whose surface was scraped to obtain the sample of microalgae, which was preserved in $70 \%$ ethanol.

The diatoms were identified to species using the technique of oxidizing the organic matter and eliminating the dissolved salts, following Battarbee (1986). Permanent preparations were made by mounting in Naphrax resin (refractive index $=1.7$ ). In each sample 300 diatom valves were identified to species under a Carl Zeiss Axioplan microscope using a 1000X immersion objective. The taxonomic identification was based on the specialized literature for each group of diatoms ([27, 39-42]; Rumrich, Lange-Bertalot \& Rumrich, 2000).

\section{Pre-treatment, ordination and classification of data}

The data analysis model was designed to detect local variation among rivers of the same basin and to detect large-scale variation among basins. Data were fourthroot transformed to reduce the effect of sampling effort and the contribution of the dominant taxa [14]. The transformed data were used to construct a Bray-Curtis similarity matrix, with which the sites were grouped using a UPGMA cluster analysis, evaluating its significance with a SIMPROF test (9999 permutations within the variables-type 1 -with a $5 \%$ significance level). The graphic representation of the significant groups and data ordination in a multivariate space was done with a principal coordinates analysis (PCO), using the combined factor $\mathrm{DgxBa}$ (D. geminata $\mathrm{x}$ Basins) to construct the intra-group centroids and estimate the variance associated with both factors.

\section{Diversity indexes}

The communities invaded and not invaded by D. geminata were compared among sites (rivers) and among basins to understand the spatial variation of the community structure at different scales. For this we calculated the univariate indexes of specific richness $(\mathrm{S})$, Shannon diversity $\left(H^{\prime} \log _{e}\right)$, Pielou's evenness $\left(J^{\prime}\right)$ and Simpson's index $(1-\lambda)$ as estimators of $\alpha$ diversity for each of the sites of the different basins. We estimated $\beta$ diversity as the species turnover between basins, calculating the multivariate dispersion with the PERMDISP program [2]. The distributions of all parameters were compared using the nonparametric Mann-Whitney test $(p<0.05)$.

\section{Multivariate analyses}

We used permutational multivariate analyses of variance (PERMANOVA) to estimate the effect and the spatial variation of $D$. geminata on the diatom community, using an orthogonal hierarchic model with 9999 permutations of the residuals and a reduced null model. As sources of variation we used the presence of $D$. geminata $(\mathrm{Dg})$ as a fixed factor with 2 levels, basin $(\mathrm{Ba})$ as a random factor with 12 levels and their combination (DgxBa). The homogeneity among groups was compared as multivariate dispersion of the combined factor (DgxBa) with the PERMDISP test [2]. We performed an analysis of percentage similarity (SIMPER) using the Bray-Curtis matrix to identify the set of species which contribute most to the intra- and inter-group similarity (invaded: $\mathrm{Dg}$ + and not invaded by $D$. geminata: $\mathrm{Dg}$-), using $70 \%$ as the lower limit of contribution. We also performed a second SIMPER analysis to estimate the similarity between the two groups of sites (invaded and non-invaded), and within each group for each basin individually, using a combined grouping factor ( $\mathrm{DgxBa})$.

The relation between $D$. geminata and the species which most contributed to the similarity of the groups was described using a simple linear regression model (STATISTICA 7). The pattern of density ( cell $/ \mathrm{mm}^{2}$ ) of the species most relevant to the dissimilarity among the groups was represented graphically using a shade plot.

We evaluated the existence of a pattern in the response of the species that contributed most to the dissimilarity between the two groups (DgxBa). This was done with a classification analysis using a species association index with non-transformed data standardized by the total number of variables (SIMPROF with 9999 permutations within the samples-type 3-, 5\% significance).

All analyses were performed with Primer v7 except for the regressions, which used Statistica 7.

\section{Results \\ General}

The analysis of cell density data revealed that D. geminata was present in 284 of the 1023 sites sampled. We identified 3 classes, 17 orders, 35 families, 79 genera and 338 diatom species. We did not find species whose distribution coincided completely with that of $D$. geminata; all species which responded to its presence were distributed in the entire study area. The species showed a wide geographic distribution in the area invaded by $D$. geminata, and we found important differences in the density of species between invaded and non-invaded rivers.

\section{Classification and ordination}

The SIMPROF test on the clusters of diatom density per site identified 5 significantly different groups $(p<0.05)$, due both to the presence of $D$. geminata and the spatial 
distribution of the sites (rivers). The combined ordination with SIMPROF (Fig. 2) explained 54\% or the variation in the data, and recognized a northern area (83, $94,101,103)$ and a southern area $(105,107,110,111$, $113,115,122,128)$, in which it is also observed that the structure of the invaded sites was significantly different from the non-invaded sites in the same basins. The group of invaded sites tended to greater homogeneity, and sites with $D$. geminata showed greater similarity than with other sites in the same basin. By contrast, the group of non-invaded sites has greater heterogeneity among basins and between distribution areas.

\section{Components of diversity}

The univariate indices showed that the invaded sites in all basins (except 128) had greater richness (Fig. 3a) and diversity (Fig. 3b). Evenness (Fig. 3c) and dominance (Fig. 3d) tended to be more homogeneous within basins but variable between them. For other hand, the species turnover estimated as the multivariate dispersion (Fig. 3e) of the combined factor DgxBa showed the opposite pattern, where the invaded sites showed significantly fewer turnover compared to the non-invaded sites in all the basins analyzed (Table 1).

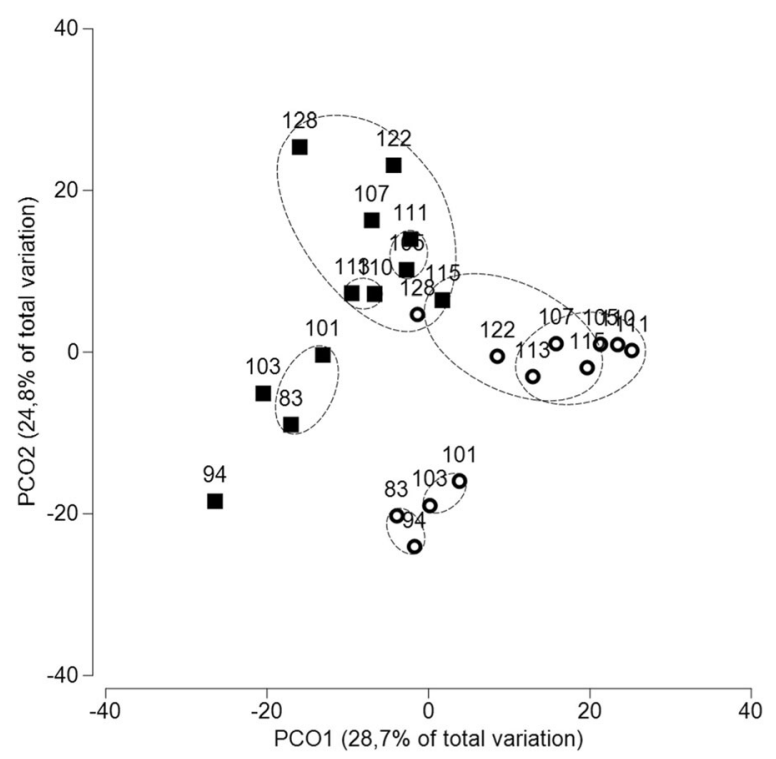

Fig. 2 Principal coordinate analysis using the combined factor DgxBa (D. geminata $\times$ basins). The numbers represent the basin codes. White circles are the non-invaded basins; black circles are the basins invaded by. D. geminata. The dashed ovals show the significant groups found by SIMPROF. Biobio River Basin (83), Tolten River Basin (94), Valdivia River Basin (101), Bueno River Basin (103), Puelo River Basin (105), Yelcho River Basin (107), Palena and coastal Rivers in the Southern Limit of the Tenth Region River Basin (110), Coastal and Island Rivers Between Palena River and Aysen River Basins (111), Aysen River Basin (113), Baker River Basin (115), Coastal Rivers Between Seno Andrew and Hollemberg River and Rivers to the East River Basins (122), and Tierra del Fuego (128)
Effect of Didymosphenia geminata on the benthic diatom communities

The PERMANOVA test indicated significant interaction between DG and the basins, that is, there were different patterns between basins considering separately the effect of D. geminata on the benthic communities (Table 2). There was also a significant effect on the internal dispersion in the basins (PERMDISP $\mathrm{F}=9.45, p=0.001$ ), which indicates that the within-group variation of the invaded and non-invaded sites was significantly different among basins. This result indicates the effect of $D$. geminata depends of internal variability and the location of the basins.

\section{Group similarity and contribution of species}

The SIMPER analysis considering the combined factor $\operatorname{DgxBa}(D$. geminata $\mathrm{x}$ Basins) showed that the groups composed exclusively of invaded sites had high mean similarity in all basins (Fig. 4). The DG factor revealed that the intra-group similarity of the invaded sites (26\%) was greater than that of the non-invaded sites (18\%); the dissimilarity between the groups was $81 \%$. All species that contributed to the similarity and dissimilarity of each group were present in both groups and in all basins. Of the 338 species included in the analysis, 10 showed a significant response to the presence of $D$. geminata; Gomphonema angustum Agardh 1831 (5.78\%), G. pumilum E. Reichardt \& Lange-Bertalot 1991 (7.43\%) and Rhoicosphenia abbreviata (C. Agardh) Lange-Bertalot 1980 (4.16\%) contributed exclusively to the similarity of the non-invaded sites, while Tabellaria flocculosa (Roth) Kützing 1844 (4.99\%), Ulnaria ulna (Nitzsch) Compère 2001 (3.93\%), Encyonema minutum (Hilse) D. G. Mann 1990 (3.04\%) and D. geminata $(17.10 \%)$ contributed exclusively to the similarity of the invaded group. The species Achnanthidium minutissimum (Kützing) Czarnecki 1994 (Dg- 32.91\%; Dg + 2.92\%), Fragilaria capucina Desmazières 1830 (Dg12.77\%; Dg + 10.57\%), F. capucina var vaucheroae (Kützing) Lange-Bertalot 1980 (Dg- 5.78\%; Dg + 3.91\%) and $H$. arcus (Dg- $3.98 \%$; $\mathrm{Dg}+4.9 \%$ ) contributed to the internal similarity of both groups. The density of all species which contributed to the similarity of the $\mathrm{Dg}+$ group showed positive and significant correlation with the density of D. geminata (Fig. 5).

All the species were present in both groups; the Dg + group concentrated the greatest densities (Figs. 6 and 7). The density pattern of $D$. geminata showed significant differences (SIMPROF $p<0.05$ ) with respect to the patterns of F. capucina, F. capucina v vaucheriae, A. minutissimum, Hannaea arcus (Ehrenberg) R. M. Patrick 1966, Staurosirella pinnata (Ehrenberg) D. M. Williams \& Round 1988, Cymbella cistula (Ehrenberg) O. Kirchner 1878, Distrionella gemainii (Reichardt \& LangeBertalot) Morales, Bahls \& Cody 2005 and T. flocculosa. 


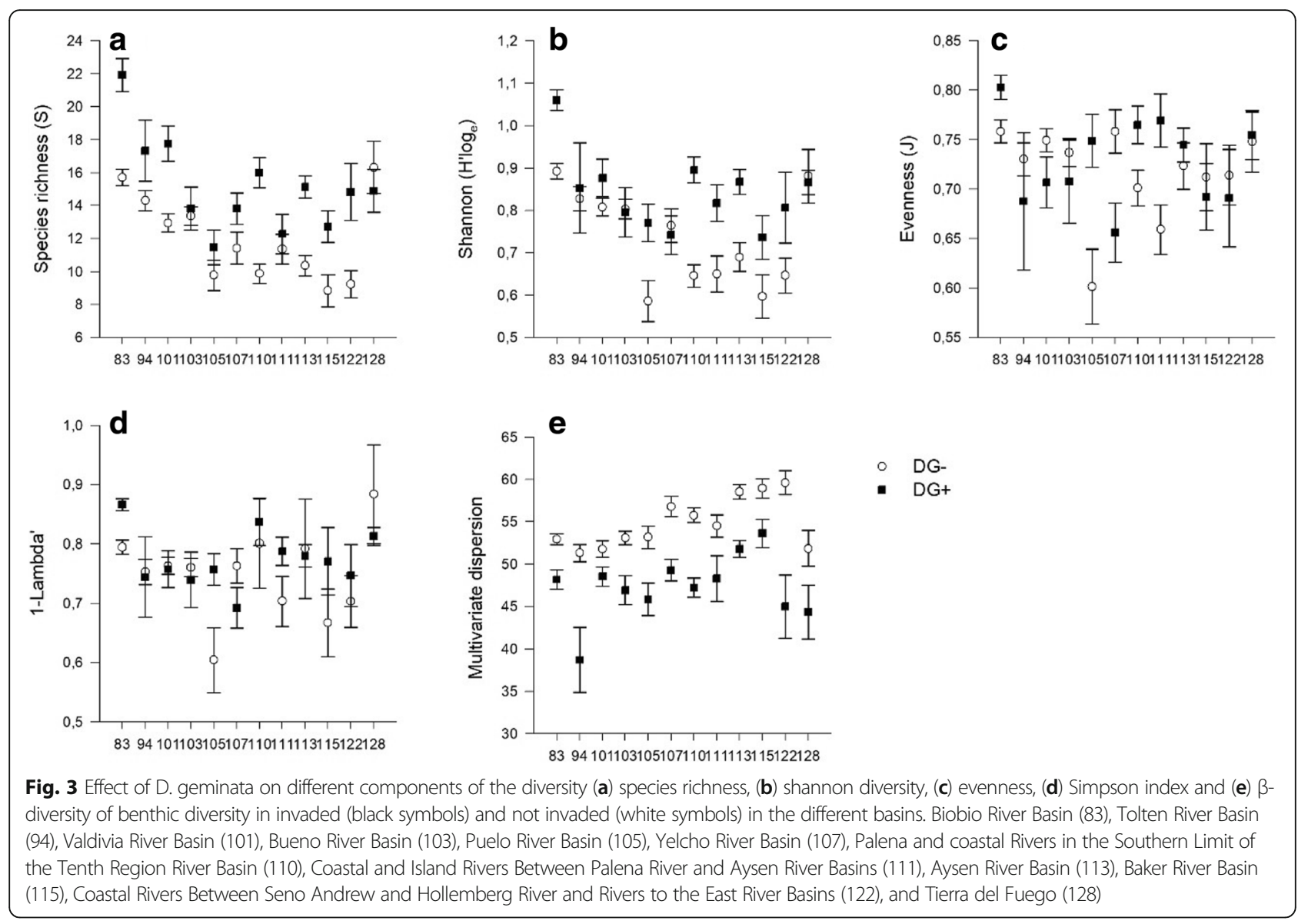

\section{Discussion}

The results of this study provide relevant information about the effect that $D$. geminata produces on the structure of benthic diatom communities in Chilean rivers, which is reflected in the community structure through a broad geographical area invaded in Chile. The structure show clearly that community variability decreased within sites invaded by $D$. geminata suggesting community homogenization was occurring. Very few studies have shown this type impact on the benthic microalgal

Table 1 Number of samples and diversity parameters estimated for the invaded (Dg+) and not invaded (Dg-) in each studied basin

\begin{tabular}{|c|c|c|c|c|c|c|c|c|c|c|c|c|c|c|c|c|c|}
\hline \multirow[t]{2}{*}{ Watershed } & \multicolumn{2}{|c|}{$\mathrm{N}^{\circ}$ of samples } & \multicolumn{3}{|c|}{ Richness (S) } & \multicolumn{3}{|c|}{ Shannon $\left(\mathrm{Hlog}_{\mathrm{e}}\right)$} & \multicolumn{3}{|c|}{ Pilou evenness $\left(J^{\prime}\right)$} & \multicolumn{3}{|c|}{ Simpson $(1-\lambda)$} & \multicolumn{3}{|c|}{ Multivariate dispersion } \\
\hline & $\overline{\mathrm{DG}-}$ & DG+ & $\bar{U}$ & $z$ & $\overline{p \text {-level }}$ & $\bar{U}$ & Z & $\overline{p \text {-level }}$ & $\bar{U}$ & $\bar{Z}$ & $\overline{p \text {-level }}$ & $\bar{U}$ & Z & $\overline{p \text {-level }}$ & $\bar{U}$ & $\bar{Z}$ & $p$-level \\
\hline 83 & 115 & 38 & 934 & $-5,28$ & $0,05<$ & 205 & $-4,42$ & $0,05<$ & 1782 & $-1,70$ & 0,09 & 1304 & $-3,72$ & $0,05<$ & 1406 & 3,29 &, $05<$ \\
\hline 1 & 76 & 3 & 62 & $-1,35$ & 0,18 & 109 & $-0,13$ & 0,90 & 71 & 1,08 & 0,28 & 87 & 0,69 & 0,49 & 24 & 2,31 & $0,05<$ \\
\hline 101 & 105 & 30 & 829 & $-3,95$ & $0,05<$ & 1245 & $-1,75$ & 0,08 & 1291 & 1,50 & 0,13 & 1486 & $-0,47$ & 0,64 & 1323 & 1,33 & 0,18 \\
\hline 103 & 95 & 11 & 468 & $-0,56$ & 0,57 & 512 & 0,11 & 0,91 & 443 & 0,77 & 0,44 & 487 & 0,31 & 0,75 & 288 & 2,43 & $0,05<$ \\
\hline 105 & 33 & 19 & 225 & $-1,68$ & 0,09 & 189 & $-2,37$ & $0,05<$ & 187 & $-2,40$ & $0,05<$ & 181 & $-2,40$ & $0,05<$ & 149 & 3,13 & $0,05<$ \\
\hline 107 & 26 & 29 & 295 & $-1,39$ & 0,16 & 361 & 0,27 & 0,79 & 236 & 2,38 & $0,05<$ & 304 & 1,01 & 0,31 & 160 & 3,66 & $0,05<$ \\
\hline 110 & 91 & 38 & 737 & $-5,13$ & $0,05<$ & 482 & $-5,19$ & $0,05<$ & 1295 & $-2,16$ & $0,05<$ & 1047 & $-3,32$ & $0,05<$ & 649 & 5,58 & $0,05<$ \\
\hline 111 & 46 & 14 & 290 & $-0,56$ & 0,58 & 216 & $-1,85$ & 0,06 & 163 & $-2,63$ & $0,05<$ & 241 & $-1,22$ & 0,22 & 216 & 1,85 & 0,06 \\
\hline 113 & 71 & 64 & 1153 & $-4,93$ & $0,05<$ & 1389 & $-3,89$ & $0,05<$ & 2140 & $-0,31$ & 0,76 & 1590 & $-2,18$ & $0,05<$ & 1205 & 4,70 & $0,05<$ \\
\hline 15 & 33 & 22 & 211 & $-2,61$ & $0,05<$ & 268 & $-1,63$ & 0,10 & 298 & 0,78 & 0,44 & 245 & 1,05 & 0,30 & 191 & 2,95 & $0,05<$ \\
\hline 122 & 29 & 6 & 33 & $-2,36$ & $0,05<$ & 56 & $-1,36$ & 0,17 & 77 & 0,44 & 0,66 & 69 & $-0,79$ & 0,43 & 23 & 2,80 & $0,05<$ \\
\hline 128 & 15 & 10 & 61 & 0,80 & 0,42 & 56 & 1,05 & 0,29 & 66 & 0,50 & 0,62 & 52 & 1,28 & 0,20 & 23 & 2,88 & $0,05<$ \\
\hline
\end{tabular}


Table 2 Results of the PERMANOVA test to estimate the effect and spatial variation of D. geminata on the diatom community in Chilean rivers. The sources of variation considered in the analyses were PA: Presence / Absence of D. geminata, Ba: basins, the combined factor PAxBa and Res: Residuals

\begin{tabular}{|c|c|c|c|c|c|c|c|}
\hline Source & $d f$ & SS & MS & Pseudo-F & $P($ perm) & Unique perms & $P(M C)$ \\
\hline$\overline{P A}$ & 1 & 71,249 & 71,249 & 15.263 & 0.001 & 999 & 0.001 \\
\hline Wa & 11 & 223,730 & 20,339 & 7.0661 & 0.001 & 991 & 0.001 \\
\hline PAxWa & 11 & 63,151 & 5741 & 1.9945 & 0.001 & 996 & 0.001 \\
\hline Res & 995 & $2,864,000$ & 2878.4 & & & & \\
\hline Total & 1018 & $3,391,100$ & & & & & \\
\hline
\end{tabular}

communities [10]. Studies like Sivarajah et al. [67] and Gillis \& Lavoie [24] found that D. geminata proliferations altered benthic diatom community composition and biomass, but with a minimal impact on overall diatom assemblage composition. The great similarity among the invaded rivers founds in this study, complements those results, and is an indication of the strong transformer capacity of D. geminata, which is capable of leading to a community structure which is more homogeneous and different than those of the non-invaded rivers and disrupting the biogeographic heterogeneity of the invaded area.

Although the general pattern indicates the homogenization of the community, D. geminata induced multiple responses. This condition is reflected in the general diversity pattern, where at local scale, the invaded sites, were more diverse than non-invaded rivers, while beta diversity changes indicate that $D$. geminata causes reduced species turnover compared to non-invaded sites. This inverse pattern has been observed in other systems affected by biological invasions, in which the invaders induce responses that varies with the spatial scale $[15,26]$, and may be indicates that broad scale was more appropriately to examined the effects of $D$. geminata on the communities [10]. The high species richness and diversity associated to local changes in invaded rivers are similar to that described at local scales for rivers of New Zealand [24] and in the high zone of the Biobío River Basin in Chile [21]. Increased diversity may be related to the mucilagenous stalks of $D$. geminata that offer a habitat for small species of stalked diatoms to settle and increase their density, even surpassing that of D. geminata and of other native species [22]. This kind of interaction gives rise to the dominance of species capable of establishing positive associations with D. geminata, and thus increases the similarity among the communities of a given geographic area invaded by it.

Basins are highly heterogeneous units with high internal dispersion [28] that influences the reconfiguration of the communities when faced with invaders $[2,15]$. The high similarity among invaded rivers of different basins in contrast to non-invaded rivers is a response that reflects the magnitude of the changes induced by $D$. geminata, which leads specifically to a community dominated by species of the Order Cymbellales such as $A$. minutissimum, which dominate in more than $90 \%$ of the

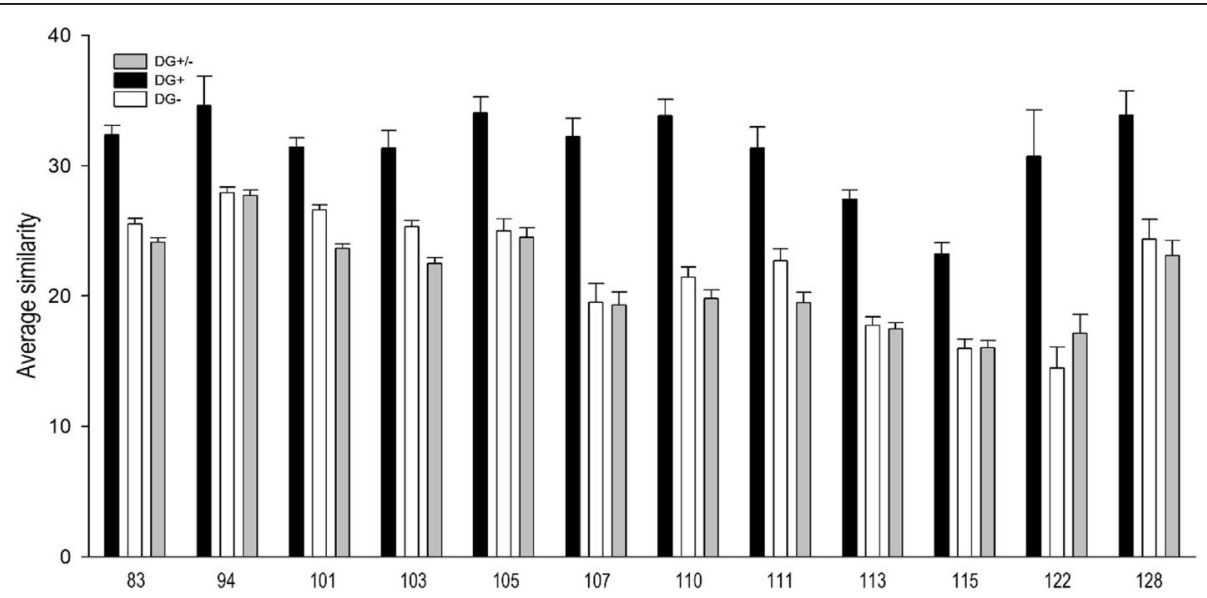

Fig. 4 Similarity values calculated for the groups of invaded sites ( $\mathrm{Dg}+$, black bars), non-invaded sites (Dg-, white bars) and the comparison between them (Dg+/Dg-, grey bars) in the basins (numbers). Note that the invaded basins have greater similarities than the non-invaded basins. Biobio River Basin (83), Tolten River Basin (94), Valdivia River Basin (101), Bueno River Basin (103), Puelo River Basin (105), Yelcho River Basin (107), Palena and coastal Rivers in the Southern Limit of the Tenth Region River Basin (110), Coastal and Island Rivers Between Palena River and Aysen River Basins (111), Aysen River Basin (113), Baker River Basin (115), Coastal Rivers Between Seno Andrew and Hollemberg River and Rivers to the East River Basins (122), and Tierra del Fuego (128) 

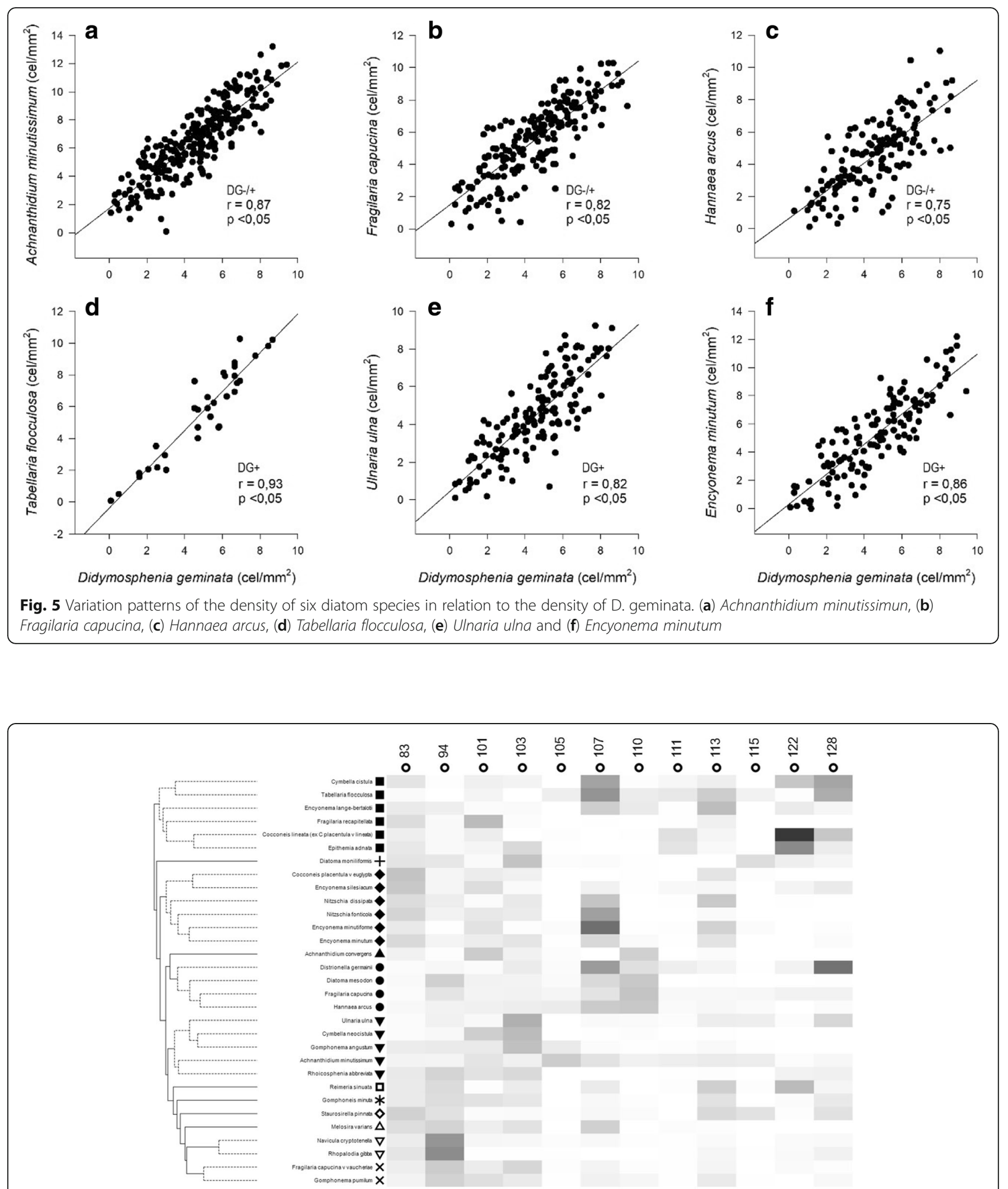

Fig. 6 Shade plot showing the distribution of density of the species (listed at the left) with the greatest contibution to the structure of the groups of sites not invaded by D. geminata in the studied basins (numbers above the graph). The left side of the figure show the clustering with the significant groups (dashed lines) identified by SIMPROF. Biobio River Basin (83), Tolten River Basin (94), Valdivia River Basin (101), Bueno River Basin (103), Puelo River Basin (105), Yelcho River Basin (107), Palena and coastal Rivers in the Southern Limit of the Tenth Region River Basin (110), Coastal and Island Rivers Between Palena River and Aysen River Basins (111), Aysen River Basin (113), Baker River Basin (115), Coastal Rivers Between Seno Andrew and Hollemberg River and Rivers to the East River Basins (122), and Tierra del Fuego (128) 


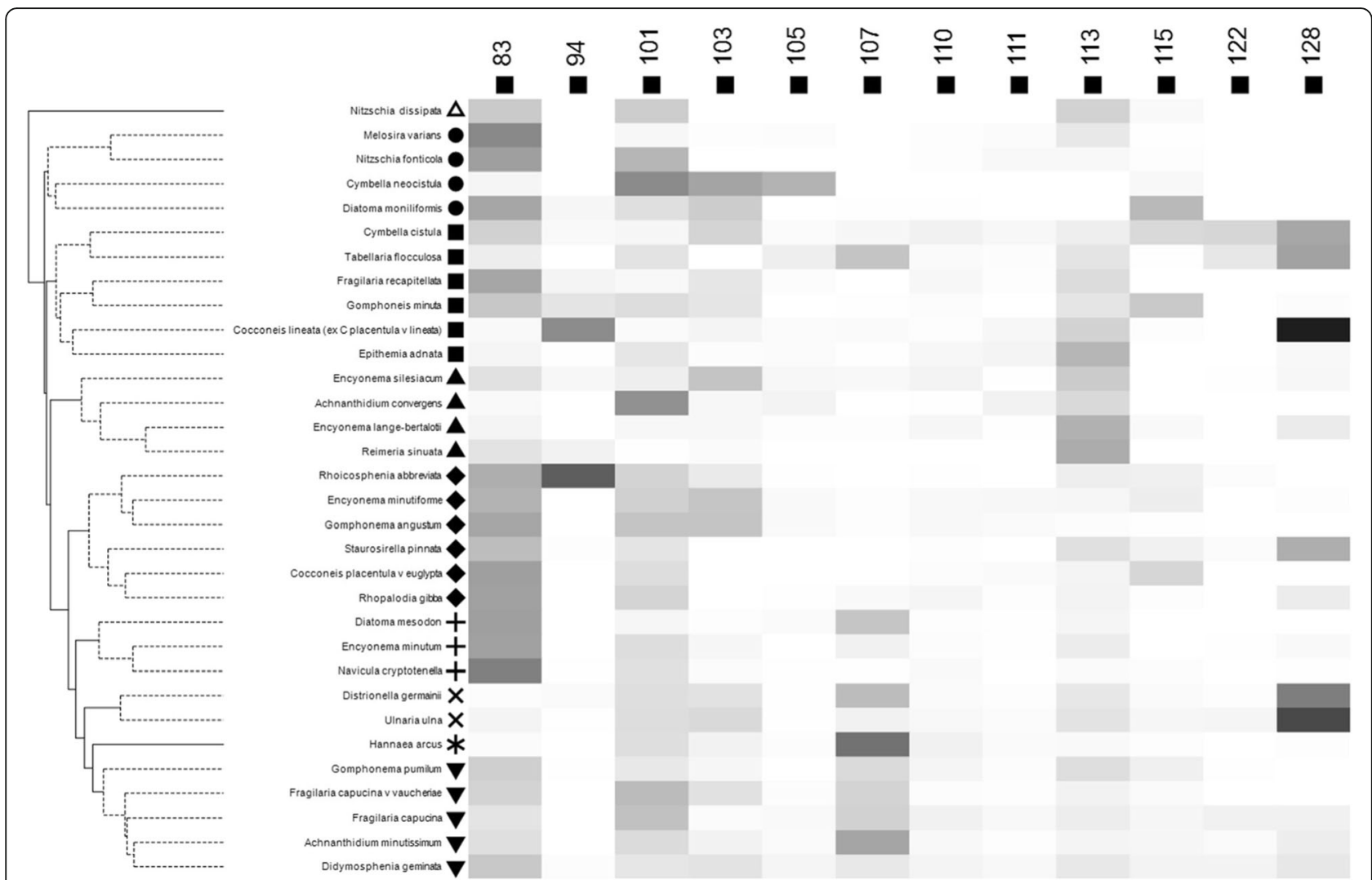

Fig. 7 Shade plot showing the distribution of density of the species (listed at the left) with the greatest contibution to the structure of the groups of sites invaded by D. geminata in the studied basins (numbers above the graph). The left side of the figure show the clustering with the significant groups (dashed lines) identified by SIMPROF. Biobio River Basin (83), Tolten River Basin (94), Valdivia River Basin (101), Bueno River Basin (103), Puelo River Basin (105), Yelcho River Basin (107), Palena and coastal Rivers in the Southern Limit of the Tenth Region River Basin (110), Coastal and Island Rivers Between Palena River and Aysen River Basins (111), Aysen River Basin (113), Baker River Basin (115), Coastal Rivers Between Seno Andrew and Hollemberg River and Rivers to the East River Basins (122), and Tierra del Fuego (128). (DG+/-) species was present in invaded and no invaded sites, (DG+) species presents only in invaded sites

invaded sites. The relation between these two species and the dominance of $A$. minutissimum in rivers invaded by $D$. geminata has also been reported in rivers of Italy, Poland, Canada and New Zealand [5, 24, 33], indicating the mechanisms of colonization and the effects of $D$. geminata may even overcome the scale effect at large scales.

The community similarity among invaded sites is produced by the effect that $D$. geminata has on the density of certain species. This specific group may establish interspecies associations whose intensity and direction are spatially variable. Encyonema minutum, Tabellaria flocculosa and Ulnaria ulna are among the taxa recorded whose density increased significantly; they also inhabit oligotrophic areas and develop a mucilaginous stalk, but differ in the size of their cells. These species grow indistinctly on diverse rocky, plant and animal substrates $[16,19,38]$, and the colonial structure of $D$. geminata may also provide a substrate that favors their proliferation and contributes to the local diversity of the invaded rivers.
Although the presence and expansion of D. geminata affects the set of resident species, some of them have greater sensitivity to the changes, clearly shown through the variations in their density. Interpreting this pattern based on the taxonomic composition of each site allows us to infer how some species respond similarly to the presence of $D$. geminata. This similarity is observed in the strong association among some species, which depends on the density of each $[13,18,47]$. Given that $D$. geminata affects the density of a specific group of diatoms, the type and intensity of the association among them would also respond to the presence of this invader. This is reflected in that the species whose density tends to increase in the invaded rivers differ in the degree of interspecific association, indicating that the responses are not uniform, and that the communities exhibit multiple responses to the presence of D. geminata. Finally, the pattern of density based on the taxonomic composition indicates that the set of invaded sites form a group with less variety of responses or associations compared 
to the set of non-invaded sites. This indicate that $D$. geminata proliferation induces an empoverishment of diversity, leading to a homogeneous taxonomic on the benthic diatom community capable of predominating in an extensive geographic region.

\section{Conclusions}

The benthic diatom communities in the Chilean rivers invaded by $D$. geminata show responses similar to those described in other regions of the world and to those produced by other types of invaders. This diatom has become established in the resident communities and constitutes a new and potent threat to the integrity of the freshwater biota in temperate, oligotrophic lotic environments, especially those of south-central Chile. The ecology invasion of $D$. geminata suggest that this species should be considered an ecosystem engineer and a transformer due the shifts induced on communities related to trophic interactions and habitat alteration [10, 31, 73].

The main effect found in this study was the homogenization of the benthic diatom communities, which is reflected in the increase in density of small stalked diatoms and the reduction of species turnover of invaded rivers among basin. Although we did not detect signals of species exclusion, $D$. geminata favors a particular group of diatom species which in the long run may displace others and thus trigger different types of impacts, including alterations in the fluvial trophic webs [44]. The effect of $D$. geminata may be expressed in different components of diversity and may surpass the effect of spatial scale. Invaded sites are clearly distinguished from non-invaded sites independent of their distribution, demonstrating that the invasion and dispersion of this species leads to a largescale loss of diversity in diatoms communities.

The species most sensitive to the presence of $D$. geminata coexist with it and lack a uniform response among the sites (by basin). However, the community structure expresses signals of homogenization mediated by the predominance of species whose densities increase with the presence of $D$. geminata. Some of these species show a high degree of association in their responses and vary similarly in the set of invaded sites. However, there is a larger number of groups of response in the non-invaded sites, confirming that the invaded sites are also losing functional diversity. Thus our results support the hypothesis that the sites invaded by $D$. geminata share a common community structure which is less diverse and significantly different than that of sites not invaded by this diatom, leading to the loss of community heterogeneity that overcomes the spatial heterogeneity of the area invaded in Chile.

\section{Abbreviations}

Ba: Basin; df: Degrees of freedom; Dg +: Presence of Didymosphenia geminata.; Dg-: Absence of Didymosphenia geminata; Dg: Didymophenia geminata; DgxBa: Combinated factor Didymosphenia geminata $\mathrm{x}$ basin; $H^{\prime}$ loge: Shannon diversity base natural logarithm; J': Equitability; MS: Mean squares; P(MC): Monte Carlo P-values; P(perm): Permutation P-value; PA: Presence / Absence of D. geminata; PCO: Principal Coordinates Ordenation; PERMANOVA: Permutational multivariate analyses of variance; PERMDISP: Multivariate dispersion; Pseudo-F: Pseudo-F ratio; S: Species richness; SIMPER: Similitary percentage analyses; SS: Sums of squares; PAxBa: Combinated factor Presence / Absence of D. geminata $x$ basin

\section{Acknowledgements}

The authors thank the Subsecretaria de Economía y Empresas de Menor Tamaño del Estado de Chile for funding this study. To Alejandro Barrientor Puga and Daniel Segura Vergara of Unidad de Gestión Sanitaria y Plagas de la Subsecretaría de Pesca y Acuicultura for his invaluable contributions to the execution of the Monitoring. To Karina Diaz Valle for the sample identification and we thanks to Carlos Velásquez G., Marcelo Soto M, Yaritza Burgos V, and Hector Tardón S. for their valuable participation in the fieldwork.

\section{Authors' contributions}

AOP participated in the field and laboratory work, interpretation of results and manuscript drafting. JSP participated in the field and laboratory work, carried out design and draft the manuscript, carried out design, data analysis and interpretation of results. Both authors read and approved the final manuscript.

\section{Authors' information}

JSP senior researcher and leader researcher of Monitoring program for the plague species Didymosphenia geminata in bodies of water in the southern central zone, Phase | 2016-2017, Phase || 2017-2018, Phase III 2018-2019, Biologist PhD Environmental Sciences. AOP senior researcher of Monitoring program for the plague species Didymosphenia geminata in bodies of water in the southern central zone, Phase | 2016-2017, Phase || 2017-2018, Phase III 2018-2019, Biologist PhD Environmental Sciences.

\section{Funding}

This study was funded by Subsecretaría de Economía y Empresas de Menor Tamaño del Estado de Chile, financed to Instituto de Fomento Pesquero (IFOP) the execution of the "Monitoring program for the plaque species Didymosphenia geminata in bodies of water in the southern central zone, Phase I 2016-2017".

Availability of data and materials

Please contact author for data requests.

Ethics approval and consent to participate

Not applicable.

Consent for publication

Not applicable.

Competing interests

The authors declare that they have no competing interests.

Received: 30 December 2018 Accepted: 18 June 2019

Published online: 22 July 2019

\section{References}

1. Abell R, Thieme ML, Revenga C, Bryer M, Kottelat M, Bogutskaya N, Coad B, Mandrak N, Balderas SC, Bussing W. Freshwater ecoregions of the world: a new map of biogeographic units for freshwater biodiversity conservation. BioScience. 2008:58:403-14.

2. Anderson $\mathrm{MJ}$, Ellingsen $\mathrm{KE}, \mathrm{Mcardle} \mathrm{BH}$. Multivariate dispersion as a measure of beta diversity. Ecol Lett. 2006;9:683-93.

3. Asprey GF, Benson-Evans K, Furet JE. A contribution to the study of South American freshwater phytoplankton. Concepción: Universidad de Concepción; 1964

4. Basualto S, Rivera P, Cruces F, Ector L, Ascencio E. Didymosphenia geminata (Lyngbye) M. Schmidt y Gomphoneis minuta (Stone) Kociolek \& Stoermer (Bacillariophyta), especies presentes en ríos de la VIII 
Región, Chile, formadoras de proliferaciones con aspecto muy similar. Gayana. Botánica. 2016;73:457-61.

5. Beltrami ME, Cappelletti C, Ciutti F, Hoffmann L, Ector L. The diatom Didymosphenia geminata: distribution and mass occurrence in the province of Trento (northern Italy). Internationale Vereinigung für theoretische und angewandte Limnologie: Verhandlungen. 2008:30:593-7.

6. Blanco S, Ector L. Distribution, ecology and nuisance effects of the freshwater invasive diatom Didymosphenia geminata (Lyngbye) M. Schmidt: a literature review. Nova Hedwigia. 2009;88:347-422.

7. Bothwell ML, Taylor BW. Blooms of benthic diatoms in phosphorus-poor streams. Front Ecol Environ. 2017;15:110-1.

8. Bothwell ML, Lynch DR, Wright $H$, Deniseger J. On the boots of fishermen: the history of Didymo blooms on Vancouver Island, British Columbia. Fisheries. 2009;34:382-8.

9. Bothwell ML, Taylor BW, Kilroy C. The Didymo story: the role of low dissolved phosphorus in the formation of Didymosphenia geminata blooms. Diatom Res. 2014;29:229-36.

10. Bray J. The invasion ecology of Didymosphenia geminata. A thesis submitted in partial fulfilment of the requirements for the Degree of Doctor of Philosophy University of Canterbury; 2014.

11. Bray J, Kilroy C, Gerbeaux P, Harding JS. Ecological eustress? Nutrient supply, bloom stimulation and competition determine dominance of the diatom Didymosphenia geminata. Freshw Biol. 2017a;62(8):1433-42.

12. Bray J, O'Brien J, Harding JS. Production of phosphatase and extracellular stalks as adaptations to phosphorus limitation in Didymosphenia geminata (Bacillariophyceae). Hydrobiologia. 2017b;784(1):51-63.

13. Cáceres MD, Legendre P. Associations between species and groups of sites: indices and statistical inference. Ecology. 2009;90:3566-74.

14. Clarke K, Gorley R. (2001)PRIMER v6: User Manual/Tutorial. Plymouth: PRIMER-E; 2006.

15. Crooks JA. Characterizing ecosystem-level consequences of biological invasions: the role of ecosystem engineers. Oikos. 2002;97:153-66.

16. D'alelio D, Cante MT, Russo GF, Totti C, De Stefano M. Epizoic diatoms on gastropod shells. In: Dubinsky Z, Seckbach J, editors. All Flesh is Grass: PlantAnimal Interrelationships. Dordrecht: Springer Netherlands; 2011. p. 345-64.

17. Díaz C., Molina X. \& Montecino V. (2012) Manual para el Monitoreo e Identificación de la Microalga Bentónica Didymosphenia geminata. Segunda Edición. Subsecretaría de Pesca y Acuicultura, Gobierno de Chile. http:// www.subpesca.cl/portal/618/articles-80177documento.pdf

18. Dice LR. Measures of the amount of ecologic association between species Ecology. 1945;26:297-302.

19. Douglas B. The ecology of the attached diatoms and other algae in a small stony stream. J Ecol. 1958;46:295-322.

20. Ellwood NTW, Whitton BA. Importance of organic phosphate hydrolyzed in stalks of the lotic diatom Didymosphenia geminata and the possible impact of atmospheric and climatic changes. Hydrobiologia. 2007;592:121-33. https://doi.org/10.1007/s10750-007-0728-0.

21. Fiqueroa F, Pedreros P, Cruces F, Abdala-Díaz R, Hernández V, Becerra J, Urrutia R. Effect of Didymosphenia geminata coverage on the phytobenthic community in an Andean basin of Chile. Rev Chil Hist Nat. 2018:91(1):10. https://doi.org/10.1 186/s40693-018-0080-y.

22. Flöder S, Kilroy C. Didymosphenia geminata (Protista, Bacillariophyceae) invasion, resistance of native periphyton communities, and implications for dispersal and management. Biodivers Conserv. 2009:18:3809.

23. Gillis C-A, Chalifour M. Changes in the macrobenthic community structure following the introduction of the invasive algae Didymosphenia geminata in the Matapedia River (Québec, Canada). Hydrobiologia. 2010;647:63-70.

24. Gillis C-A, Lavoie I. A preliminary assessment of the effects of Didymosphenia geminata nuisance growths on the structure and diversity of diatom assemblages of the Restigouche River basin, Quebec, Canada. Diatom Res. 2014;29:281-92

25. Gillis CA, Dugdale SJ, Bergeron NE. Effect of discharge and habitat type on the occurrence and severity of Didymosphenia geminata mats in the Restigouche River, eastern Canada. Ecohydrology. 2018;11:e1959.

26. Harrison S. Native and alien species diversity at the local and regional scales in a grazed California grassland. Oecologia. 1999;121:99-106.

27. Hartley B. An atlas of British diatoms, Balogh Scientific Books; 1996.

28. Heino J, Melo AS, Bini LM. Reconceptualising the beta diversityenvironmental heterogeneity relationship in running water systems. Freshw Biol. 2015;60:223-35.

29. Jamoneau A, Passy SI, Soininen J, Leboucher T, Tiso Rosebery J. Beta diversity of diatom species and ecological guilds: response to environmental and spatial mechanisms along the stream watercourse Freshw Biol. 2018:63(1):62-73.

30. Jaramillo A, Osman D, Caputo L, Cardenas L. Molecular evidence of a Didymosphenia geminata (Bacillariophyceae) invasion in Chilean freshwater systems. Harmful Algae. 2015;49:117-23.

31. Jones CG, Lawton JH, Shachak M. Organisms as ecosystem engineers. In: Ecosystem management. New York: Springer; 1994. p. 130-47.

32. Jones $\mathrm{CG}$, Lawton JH, Shachak M. Positive and negative effects of organisms as physical ecosystem engineers. Ecology. 1997;78:1946-57.

33. Kawecka B, Sanecki J. Didymosphenia geminata in running waters of southern Poland-symptoms of change in water quality? Hydrobiologia. 2003:495:193-201.

34. Kemp JS, Aldridge DC. Comparative functional responses to explain the impact of sympatric invasive bivalves (Dreissena spp.) under different thermal regimes. J Molluscan Stud. 2018;84:175-81.

35. Kilroy C, Novis P. Is Didymosphenia geminata an introduced species in New Zealand? Evidence from trends in water chemistry, and chloroplast DNA. Ecol Evol. 2018;8:904-19.

36. Kilroy C, Unwin M. The arrival and spread of the bloom-forming freshwater diatom, Didymosphenia geminata, in New Zealand. Aquat Invasions. 2011:6:249-62.

37. Kilroy C, Larned S, Biggs B. The non-indigenous diatom Didymosphenia geminata alters benthic communities in New Zealand rivers. Freshw Biol. 2009:54:1990-2002.

38. Knudson BM, Kipling T. Ecology of the epiphytic diatom Tabellaria flocculosa (Roth) Kutz. var. flocculosa in three English lakes. J Ecol. 1957;45:93-112.

39. Krammer K, Lange-Bertalot H. Süsswasserflora von Mitteleuropa. Bacillariophyceae. 1. Teil: Naviculaceae, vol 2/1. Book in German. Jena: G. Fischer Verlag; 1986

40. Krammer K, Lange-Bertalot H. Bacillariophyceae. 4. Teil: Achnanthaceae. Süsswasserflora von Mitteleuropa. Band 2/4. Stuttgart, Jena: Fischer; 1991a. p. 437.

41. Krammer K, Lange-Bertalot H. Susswasserflora von Mitteleuropa. Bacillariophyceae Teil iv: Achnanthaceae. Gustav Fischer Verlag: Stuttgart; $1991 \mathrm{~b}$.

42. Krammer K, Lange-Bertalot H. Süsswasserflora von Mitteleuropa 2: Bacillariophyceae. Teil 4: Achnanthaceae. Kritische Ergänzungen zu Achnanthes sl, Navicula s. str., Gomphonema. Heidelberg: Spektrum Akademischer Verlag/Gustav Fischer; 2004

43. Kunza LA, Gillis CA, Haueter JZ, Murdock JN, O'brien JM. Declining phosphorus as a potential driver for the onset of Didymosphenia geminata mats in north American rivers. River Res Appl. 2018;34(8): 1105-10.

44. Ladrera R, Gomà J, Prat N. Effects of Didymosphenia geminata massive growth on stream communities: smaller organisms and simplified food web structure. PLoS One. 2018;13:e0193545.

45. Lamberti GA, Hauer FR. Methods in stream ecology. San Diego: Elsevier: 1996. p. $358-380$

46. Larned ST, Packman Al, Plew DR, Vopel K. Interactions between the matforming alga Didymosphenia geminata and its hydrodynamic environment. Limnol Oceanogr. 2011;1:4-22.

47. Legendre P, Legendre L. Complex ecological data sets. In: Numerical ecology (Vol. 24). Amsterdam: Elsevier; 2012.

48. Leprieur F, Beauchard O, Blanchet S, Oberdorff T, Brosse S. Fish invasions in the world's river systems: when natural processes are blurred by human activities. PLoS Biol. 2008:6:e28.

49. Lodge DM, Taylor CA, Holdich DM, Skurdal J. Nonindigenous crayfishes threaten north American freshwater biodiversity: lessons from Europe. Fisheries. 2000;25:7-20

50. Macdougall MJ, Paterson AM, Winter JG, Jones FC, Knopf LA, Hall Rl. Response of periphytic diatom communities to multiple stressors influencing lakes in the Muskoka River watershed, Ontario, Canada. Freshwat Sci. 2017;36:77-89.

51. Marinković N, Krizmanić J, Karadžić V, Karadžić B, Vasiljević B, Paunović M. Algal diversity along the Serbian stretch of the Sava River; 2016.

52. Mcgeoch MA, Butchart SH, Spear D, Marais E, Kleynhans EJ, Symes A, Chanson J, Hoffmann M. Global indicators of biological invasion: species numbers, biodiversity impact and policy responses. Divers Distrib. 2010;16:95-108.

53. Melo AS, Schneck F, Hepp LU, Simões NR, Siqueira T, Bini LM. Focusing on variation: methods and applications of the concept of beta diversity in aquatic ecosystems. Acta Limnologica Brasiliensia. 2011;23(3):318-31. 
54. Montecino V, Molina X, Bothwell M, Muñoz P, Carrevedo M, Salinas F, Kuma S, Castillo M, Bizama G, Bustamante R. Spatio temporal population dynamics of the invasive diatom Didymosphenia geminata in central-southern Chilean rivers. Sci Total Environ. 2016:568:1135-45.

55. Montecino V, Molina X, Kumar S, Castillo ML, Bustamante R. Niche dynamics and potential geographic distribution of Didymosphenia geminata (Lyngbye) M. Schmidt, an invasive freshwater diatom in southern Chile. Aquat Invasions 9; 2014. https://doi.org/10.3391/ai.2014.9.4.09.

56. Moorhouse TP, Macdonald DW. Are invasives worse in freshwater than terrestrial ecosystems? Wiley Interdiscip Rev Water. 2015;2:1-8.

57. Olivares P, Orellana P, Guerra G, Peredo-Parada M, Chavez V, Ramirez A, Parodi J. Water contaminated with Didymosphenia geminata generates changes in Salmo salar spermatozoa activation times. Aquat Toxicol. 2015;163:102-8.

58. Panlasigui S, Davis AJ, Mangiante MJ, Darling JA. Assessing threats of nonnative species to native freshwater biodiversity: conservation priorities for the United States. Biol Conserv. 2018;224:199-208.

59. Parra O, Bicudo C. Introducción a la biología y sistemática de las algas de aguas continentales. Concepción: Ediciones Universidad de Concepción; 1996.

60. Polvi LE, Sarneel JM. Ecosystem engineers in rivers: an introduction to how and where organisms create positive biogeomorphic feedbacks. Wiley Interdiscip Rev Water. 2018;5:e1271.

61. Reid B, Torres R. Didymosphenia geminata invasion in South America: ecosystem impacts and potential biogeochemical state change in Patagonian rivers. Acta Oecol. 2014;54:101-9.

62. Reid BL, Hernández KL, Frangópulos M, Bauer G, Lorca M, Kilroy C, Spaulding S. The invasion of the freshwater diatom Didymosphenia geminata in Patagonia: prospects, strategies, and implications for biosecurity of invasive microorganisms in continental waters. Conserv Lett. 2012;5:432-40.

63. Resh VH, Brown AV, Covich AP, Gurtz ME, Li HW, Minshall GW, Reice SR, Sheldon AL, Wallace JB, Wissmar RC. The role of disturbance in stream ecology. J N Am Benthol Soc. 1988;7:433-55.

64. Rivera P, Gebauer M. Diatomeas chilenas en las Colecciones de Boyer, Cleve \& Moeller, Schulze y Smith, depositadas en la Academia de Ciencias Naturales de Filadelfia, Estados Unidos. Gayana Botánica. 1989;46:89-116.

65. Rivera P, Basualto S, Cruces F. Acerca de la diatomea Didymosphenia geminata (Lyngbye) M. Schmidt: su morfología y distribución en Chile, vol. 70. Gayana: Botánica; 2013. p. 154-8.

66. Rivera Ramírez P. Estado de conocimiento de las diatomeas dulceacuícolas de Chile. Gayana (Concepción). 2006;70(1):1-7.

67. Sivarajah B, Kurek J, Ruhland KM, Smol JP. Effects of Didymosphenia geminata blooms on benthic diatom assemblages in the Restigouche River watershed, eastern Canada. Botany. 2015;95(5):317-23.

68. Smol JP, Stoermer EF. The diatoms: applications for the environmental and earth sciences. Cambridge: Cambridge University Press; 2010.

69. Spaulding S, Elwell L. Increase in nuisance blooms and geographic expansion of the freshwater diatom Didymosphenia geminata: recommendations for response. White Paper USEPA Region 8; 2007.

70. Strayer DL. Alien species in fresh waters: ecological effects, interactions with other stressors, and prospects for the future. Freshw Biol. 2010;55:152-74.

71. Strayer DL, Eviner VT, Jeschke JM, Pace ML. Understanding the long-term effects of species invasions. Trends Ecol Evol. 2006;21(11):645-51.

72. Vargas PV, Arismendi I, Gomez-Uchida D. Evaluating taxonomic homogenization of freshwater fish assemblages in Chile. Rev Chil Hist Nat. 2015;88(1):16.

73. Zulkifly SB, Graham JM, Young EB, Mayer RJ, Piotrowski MJ, Smith I, Graham LE. The genus Cladophora Kützing (Ulvophyceae) as a globally distributed ecological engineer. J Phycol. 2013;49(1):1-17.

\section{Publisher's Note}

Springer Nature remains neutral with regard to jurisdictional claims in published maps and institutional affiliations.

Ready to submit your research? Choose BMC and benefit from:

- fast, convenient online submission

- thorough peer review by experienced researchers in your field

- rapid publication on acceptance

- support for research data, including large and complex data types

- gold Open Access which fosters wider collaboration and increased citations

- maximum visibility for your research: over $100 \mathrm{M}$ website views per year

At BMC, research is always in progress.

Learn more biomedcentral.com/submissions 